\title{
Academic Freedom as a Fundamental Right
}

\author{
R. Cippitani* \\ *Università degli Studi di Perugia
}

\begin{abstract}
The paper aims at defining in particular the concept of academic freedom within the context of the European legal sources.

Even though the idea of a special corporative status for professors was born during the Middle Ages, it was only during the second half of the twentieth century that the Constitutions recognised academic freedom as an individual's legal right. Such an individual right is regulated within the category of the freedom of expression, even if it is characterised by particular aspects.

Like any individual right that is recognised at the constitutional level, the freedoms of teaching and research are subject to limitations that protect other fundamental rights.

Furthermore, today the academic freedom has lost its traditional sense as a defence against public powers and is now granted to play a social function, protecting not only the corporative interests of teachers.

It can then be concluded that only through the developing of the social role of education and research, by the principles of quality, transparency and accountability, ensures the individual and institutional rights of the teachers and researchers, strengthening and upgrading the role that universities are playing in the last 900 years.
\end{abstract}

Keywords: Academic Freedom, Fundamental Rights, Accountability, Ethics rules, European Union, Bologna Process

\section{Introduction}

Despite a long history, the interest of the law in the organization of teaching and research activities has only been during the last two centuries.

More recent is the legal discipline of the role of Universities and the people involved in research and educational activities. Such a role received recognition in particular by the Constitutions and international legal sources of the second part of the twentieth century.

Furthermore, during the last three decades research and education have been included in the European integration process (especially with the Maastricht Treaty) and only in the last years have they been put in the edge of the EU policies concerning development and growth (see the «Lisbon Strategy» of 2000 and Europe 2020 of 2010), which, aim at solving the problems of the European economy, argued that the Union had to become a « knowledge-based »society (see Cippitani, 2012).

The position of the teachers and researchers in the legal framework may be described in early stages as the transit from the phases of the "privileged", the "public functions", the "constitutional right", and the "accountability".

\section{Teaching as Privilege}

Traditionally, the occupation of teacher has been conceived as a privileged position, such as it occurred in the Middle Ages.

During that period, a new social group was formed, the «intellectuals» (Le Goff, 1957), who in spite of practical difficulties, were lecturing throughout Europe, constituting a «transEuropean wave» which built the continental culture (Morin, 1987).

At that time teachers and students were grouped within associations, on the base of the scheme of the professional corporations, which deeply changed the traditional social structure which was composed of nobles, religious leaders and peasants.

From such associations born the Studii or Universitates (Borio, 2007).

The Universitates became an important social (and economic) phenomenon. Thus, the ecclesiastical and civil authorities recognised several important privileges to students 
and professors, who enjoyed a special status in matters such as jurisdiction, military service, and even tax exemptions (FerradaBórquez, 2001, 65).

However, the recognition of some kind of autonomy and privileges did not mean ideological multiculturalism or tolerance.

Initially the teaching of the classic works, like those of Aristotle were prohibited, and scholars who did not follow the official orthodoxy, such as William Occam, Giordano Bruno and, later, Galileo Galilei were pursued by the authorities.

Therefore, within the history of teaching in Europe, there also exists the tragic history of repression (Schoijet, 2009).

\section{The Professor as a Public Officer}

Another aspect regarding teaching positions is their relationship with the public powers. During the fifteenth century significant economic, social and cultural transformations were put in place, which were based on the philosophy of the Enlightenment and the affirmation of the scientific method as the dominant form of knowledge (AguilóBonet, 2009).

As Voltaire argued in his Le Siècle de Louis XIV, men of culture had to be considered as members of a unique independent Républiquelitteraire (see also Chabod, 2001, 45). However, in the following centuries a new and powerful phenomenon impacted the culture which was the birth of the national States.

During the XIX century, science and teaching became powerful tools to build on the idea of a nation and nationality (about the «method» on the construction of the «national identity», see Thiesse, 2001; Id. 1999).Science and education were no longer the product of an open and continental community of scholars, but they were nationalised. Wilhelm Von Humboldt in his «Über die innere und äußereOrganisation der höherenwissenschaftlichenAnstalten in Berlin» («On the internal and external organization of the high scientific institutions in Berlin») of 1810 underlined the role of the universities and other scientific institutions to shape the spiritual and moral culture of a Nation.

Therefore, in the nineteenth century the university model was elaborated on, and Immanuel Wallerstein defines the «modern university system» (Wallerstein, 2007, 77), as a system in which the university acts as a bureaucratic institution with full-time employed professors, characterised by reduced autonomy, being subject to the centralised decisions on educational matters by the State.

During the European totalitarianisms, especially in Italy and Germany, State control was extremely severe and the organs of the universities were appointed by the central government. The university professors were considered public officials with the duty to swear loyalty to the regime (in Italy, during Fascism, among the 1,200 university professors, only 12 refused the oath and in consequence were expelled).

\section{Academic Freedom as an Individual Right}

The Enlightenment begun to identify the freedom of teaching among the natural rights of men (Schoijet, 2009; see also Jolibert, 1993).

However, the freedom of teaching and research became rights in the technical legal sense, only by virtue of the Constitutions of the second half of the twentieth century, 
which were anticipated by the Weimar Constitution of $1919^{1}$ and the Spanish Constitution of 1931 (Article 48.3) ${ }^{2}$.

At that time, after the physical and moral destruction of the European continent, individual rights were asserted against the excessive power of the States (Álvarez Ledesma, 1998; Id., 2013a).

Today, the freedom of teaching and research are recognised by all European Constitutions, such as the paragraph 5 of the German Grundgesetz of 1949; the first paragraph of Article 33 of the Constitution of the Italian Republic of 1948; the Article 20 of the Spanish Constitution (1978); etc.

Academic freedom was also recognised and protected at the supranational and international levels, as it has happened with other individual rights in the previous century.

The international organisations have adopted several legal instruments concerning the matter. It is the case of the «World Declaration on Higher Education in the TwentyFirst Century: Vision and Action» issued by UNESCO on October 9, 1998. Similarly, the Universal Declaration of Human Rights of UN 1948, were it recognises the freedom of expression and opinion, which includes the right " to hold opinions without interference and to seek, receive and impart information and ideas through any media and regardless of frontiers. » (Article 19).

In the European law, the Charter of Fundamental Rights of the European Union recognises as a right the freedom of education and the Article 13 states that: «The arts and scientific research shall be free. Academic freedom is respected. " (For a commentary of this disposition, see Molina del Pozo\&Archontaki, 2013)

According those legal sources, the freedom of teaching and research could be considered a derivation of the freedom of expression (see Spanish Constitutional Court, herein after referred as "SCC", in the leading case of 13 February 1981, n. 5; Rodriguez De Santiago, 2012, 228) ${ }^{3}$.

However, while the freedom of expression must be accorded to every citizen without any limitation relating to the personal conditions or age (see Articles $24 \mathrm{ff}$. Charter of Fundamental Rights of the European Union), the academic freedom (including the freedom of teaching and of research) depends on professional qualities.

As matter of fact, the academic freedom is applicable only in relation to citizens professionally involved in the academic activities (Lorenzo Vázquez, 1994, 259). Not all persons enjoy of that freedom but only the «citizens teachers» (or researchers) (Pototschnig, 1971).

As a freedom that is recognised only to particular professionals, the academic freedom does not include the right to indoctrinate or distort the truth or scientific or historical truths (CámaraVillar, 1988, 2189), nor the right to propaganda (Crisafulli, 1956, 71$72)^{4}$.

With this respect, Norberto Bobbio, in the beginning of his work «The future of democracy», remembers that Max Weber, in a lecture at the University of Munich, said: «The university chairs are neither for demagogues nor for prophets».

\footnotetext{
${ }^{1}$ According to the Article 142 « Die Kunst, die Wissenschaft und ihreLehresindfrei. Der StaatgewährtihnenSchutz und nimmt an ihrerPflegeteil ».

${ }^{2}$ See the Article 48.3, which after affirming that the public professors were «official», established that «La libertad de cátedraquedareconocida y garantizada».

${ }^{3}$ See Italian Corte Costituzionale, judg. 8 July 2004, no. 256; see alsoSCC n. 5/1981, para. 7 and ECHR, judg. Campbell and Cosans v. United Kingdom, 25 February 1982, § 33, series A no. 48.

${ }^{4}$ See in Italy the judgment of the Consiglio di Stato, 21 March 1963, n. 725, in Rivistagiuridicadellascuola, 1964, 439.
} 


\section{Positive and negative contents of the Academic Freedom}

Freedom of the teachers/researchers education has both positive and negative content. The positive content involves «freedom of program », that is to say that the teacher has to determine his/her own program of studies, defining the content and system of teaching the subject, freely orienting their explanations and choosing the texts that he/she will use.

For UNESCO Recommendation above mentioned, the teachers « (...) should play a significant role in determining the curriculum » (para 28; cfr. also paragraphs 61 and 62 of joint ILO Recommendation and the UNESCO Recommendation concerning the Status of Teachers, 1966).

The freedom of program includes the choice of evaluation method. This freedom also considers the option of choosing the tools necessary to carry out the activities of teaching, particularly the respective method and teaching materials of the case (Expósito, 2012).

Nevertheless, the rights of the teachers and researchers, being related to a «freedom», have in particular a negative content, in the meaning of the prohibition of the invasion by others, especially by the public authorities (SCC n. 5/1981, para. 9; see para. 27 and 28 of the UNESCO Recommendation 1997).

This duty of abstention is applicable also to private schools and universities.

In some constitutions, such as Italy (see Article 33 of Constitution) the freedom of individuals to establish private schools is respected. This freedom potentially may conflict with the freedom of education, as rightly argued by Crisafulli $(1956,74)$.

But while the Italian Constitutional Court affirmed in the case Cordero, that the freedom of the professor would consist in joining or not joining the university, the European Court of Human Rights in the analogous case Vallauri (ECHR, judg. 20 October 2009, Vallauri v. Italy, n. 39128/05), stated that restrictions on freedom of teachers cannot go beyond the unavoidable need to protect the freedom of conscience and expression of each teacher (Mattioni, 1993, 433).

The same approach is adopted in the jurisprudence of the Spanish Constitutional Court, which affirms «Academic freedom of the teachers of these [private] schools is as full as that of teachers in public schools» that no provision establish the limitation of the freedom of the professors in order to respect the ideology of the University (TC 5/1981, para. 10).

\section{Limitations of academic freedom and research}

As an individual right, academic freedom cannot be considered as absolute and therefore it is subject to the legislative limitations (see the Italian Corte costituzionale, judg. 4 June 1958, n. 36), taking into account all the precautions needed in the case of the fundamental rights (Álvarez Ledesma, 2013b)

Thus, the academic freedom must be coordinated with other constitutional interests of equal rank, such as honour, public image, privacy, etc. (See in Italy, Cassazionepenale, judg. 7 May 2008, n. 37581)

With respect to other interests, considered as superior, such as health, the limitations of the right to teach or research are stronger.

Therefore is considered as legitimate for the State to verify the existence of cultural preparation, scientific and technical skills necessary for the exercise of professions which can affect the health of the persons (see for example the Italian Corte Costituzionalejudg. n. 36/1958 ref.).

Furthermore, the Constitutions provide that the right to education is the origin as well 
as the limit of academic freedom.

Education and «vocational and continuing training» (Article 14, para. 1 Charter of Fundamental Rights of the European Union) are considered fundamental rights of all human beings (CarmonaTinoco, 2013). Therefore, the academic freedom is instrumental to the enjoyment and realisation of the right to education; teachers must exercise their rights consistent with that purpose (see paragraph 34 of the UNESCO Recommendation 1997).

The exercise of academic freedom should take into account the age, maturity and education level of the students, in particular promoting their participation in the process of their own formation and guarantying his/her intellectual autonomy (Lozano Cutanda, 1997).

Other limits to the individual academic right and research arise from the institutional dimension in which these freedoms are developed.

In general, the teacher and the researcher must respect the organisation responsible for the educational and scientific activity and the rules governing the use of infrastructure (rooms, laboratories), and schedules of classes and exams.

A fortiori, they do not constitute, from the general point of view, illegitimate restrictions on freedom of professors and researchers, the obligation to comply with norms such as the regulation of public procurement and the rules set by the funding bodies like as the European Union (see the European Charter for Researchers) ${ }^{5}$.

\section{The Age of Accountability}

In order to grant its social function, the modern legal sources recommend the compliance of the academic freedom with principles such as transparency and accountability.

The already mentioned UNESCO Recommendation 1997 states that education should be considered a «public service» that "requires (...) a sense of personal and institutional responsibility for the education and welfare of students and of the community at large and for a commitment to high professional standards in scholarship and research. » (para. 6).

Academic research and teaching responsibilities involve a set of obligations included in the concept of «accountability» (see paragraph 22 of the UNESCO Recommendation).

Schools and universities should ensure transparency of management, including applying principles such as «honesty and transparency of accounting» like «the efficient use of resources».

To implement these principles, is essential to proceed with the evaluation of the quality of teachers and universities as established at the international level (see in particular paragraph 47 of Recommendation 1997), by European regional legal sources, by the Bologna process (Cippitani \&Gatt, 2010) and by several national regulations(Tavenas, 2004).

\section{Conclusions}

According to the previous paragraphs, the freedom of teaching and research derived from the corporatist privileges of the class of intellectuals in the Middle Ages.

As all privileges, the legal position of teacher did not have the status of right but of a

${ }^{5}$ Commission Recommendation of 11 March 2005 on the European Charter for Researchers and on a Code of Conduct for the Recruitment of Researchers. 
concession unilaterally attributed by the civil or religious power, until the power wanted. This did not prevent the repression of the teachers and the non orthodox ideas. Academic freedom became a legal right by the Constitutions of the second half of the twentieth century.

However it can be avoided the interpretation of such a right as an ancient privilege.

As matter of fact, there is a negative consequence of academic freedom today, which is the lack of transparency..

This is an old problem. Adam Smith (in his work «The Wealth of Nations» of 1776), thought that universities were the «sanctuaries» of the protection of obsolete prejudices. Today, within the pluralist and democratic State, academic freedom, although as a fundamental right must be «taken seriously » (Dworkin, 1978), however the academic freedom has lost its traditional function as a defence against the public powers (Vinokur, 2008).

This freedom, more than other rights arising from modern Constitutions, is attributed in order to play a social function (Pototschnig, 1971; Crisafulli, 1956,p. 70)

The academic freedom does not only satisfy the interests of teachers, but also those of the students and of others persons (such as parents), as well as other subjects involved in the educational process and, finally, of society as a whole (Mura, 1976, 235).

Indeed, the social relevance of modern education leads to reconsider the idea of the academic freedom as an exclusive privilege of an isolated, closed and privileged corporation.

Therefore, it can be concluded that only by the full achievement of the social function of academic activities, and through the application of principles of quality, transparency and accountability, can we ensure the rights of the teachers and allow the strengthening and upgrading of the role that universities are playing in the last 900 years.

\section{References}

Aguiló Bonet, A. J. (2009). La universidad y la globalización alternativa: justicia cognitiva, diversidad epistémica y democracia de saberes. In Nómadas. Revista Crítica de Ciencias Sociales y Jurídicas. 22, 2, Publicación Electrónica de la Universidad Complutense.

Álvarez Ledesma, M. (2013a) Derechos Humanos (Teoria General). InÁlvarez Ledesma, M. I., Cippitani R. (coord.), Diccionario analítico de Derechos humanos e integración jurídica, Roma-Perugia-México: ISEG

- (2013b) La libertad de expresión en el sistema electoral mexicano desde una perspectiva juridical. In López Montiel, G. Tamés Muñoz,E. (coord.) Libertad de expresión en el proceso electoral 2012 , Tecnológico de Monterrey-Coparmex, PNDU/ONU. México: Porrúa.

- (1998) Acerca del concepto «derechos humanos», México: McGraw Hill

Borio, C. (2007). Storiadell’Università (dalle originiaglianniottanta del XX secolo). In Sediari, T. (coord.), Cultura dell'integrazione europea. Torino: Giappichelli, pp. 47-80

Cámara Villar, G. (1988). Sobre el concepto y los fines de la educación en la constitución española. In X Jornadas de Estudio. Introducción a los Derechos Fundamentales, Ministerio de Justicia, Madrid, Vol. III, pp. 2159-2191

Chabod, F. (2001) Storiadell'idea di Europa. Bari: Laterza

Cippitani, R. (2012) El Derecho en la Sociedad del Conocimiento. Roma-Perugia: ISEG 
Cippitani, R. Gatt, S. (2009). Legal Developments and Problems of the Bologna Process within the European Higher Education Area and European Integration. In Higher Education in Europe, Vol. 34, Issue 3-4, 2009, pp. 385-397.

Crisafulli, V. (1956). La scuolanellaCostituzione. In Rivistatrimestraledirittopubblico. p. $54 \mathrm{ff}$.

Dworkin, R. (1978). Taking Rights Seriously. Harvard: Harvard University Press

Expósito, E.(2012-2013) Libertad de cátedra del profesor universitario. In Revista de Educación y Derecho/ Education and LawReview. n. 7, October 2012 - March 2013

Ferrada Bórquez, J.C. (2001) La autonomía universitaria: algunas reflexiones generales acerca de su contenido jurídico. In Estudios Sociales / Corporación de Promoción Universitaria, Santiago del Chile, no. 108 (semestre 2), p. 59-89

Fernández-Miranda Campoamor, A. (1988) De la libertad de enseñanza al Derecho a la educación. Madrid: CEURA, pp. 137-138.

Le Goff, J. (1957).Les intellectuellesauMoyenÂge. Paris:Seuil

LozanoCutanda, B. (1997) La libertad de cátedra y sus límites. In El País.monday 13 January

Lorenzo Vázquez, P. (1994) Acerca de la libertad de cátedra. In Derecho y opinión, n. 2, 1994, pp. 255-266

Molina del Pozo, C.F., Archontaki, C. Libertad de artes y de Investigación Científica, Libertad de Cátedra. InÁlvarez Ledesma, M. I., Cippitani R. (coord.), Diccionario analítico de Derechos humanos e integración jurídica, Roma-Perugia-México: ISEG

Morin, E. (1987).Penserl'Europe.Paris: Folio

Mattioni, A. (1993) Insegnamento (libertà di), en Digesto Pubblico, VIII, Torino, p. 433

Mura, A. (1976) ComentaryArticles 33-34 ItalianConstitution. In Branca, G., CommentarioallaCostituzione. Rapportietico-sociali. Bologna-Roma: Zanichelli.

Pototschnig, U. (1971) Insegnamento (libertà di). In Enciclopedia del diritto. Milano: Giuffrè, vol. XXI.

Schoijet, $M$. (2009)Libertad académica y represión: algunos antecedentes históricos. In Desacatos, n. 31, September-December. pp. 137-144

Tavenas, F. (2004) A Reference System for Indicators and Evaluation Procedures. Brussels: EUA

Thiesse, A.M. (2001). La creazionedelleidentitànazionali in Europa, trad.ital. de La Création des identitésnationales. Europe XVIII-XX siècle. Bologna: IlMulino

Wallerstein, I (2007)El universalismo europeo. El discurso del poder. Siglo XXI. Madrid 